\title{
Predisposising Factors of Uterine Myoma General Hospital
}

\author{
Rus Martini ${ }^{*}$, Tri Prasetyorini, Karningsih, Hamidah, Yomina B \\ ${ }^{1}$ Health Polytechnic Jakarta III \\ Jl. Arteri JORR, Jatiwarna, Bekasi, INDONESIA \\ ${ }^{*}$ Corresponding author's email: rusmartini [AT] yahoo.com
}

\begin{abstract}
-
Introduction and Aims : The occurrence of uterine myomas will increase morbidity in women of reproductive age. Uterine myoma is the most common benign tumor in women. This study aims to identify factors related to the occurrence of uterine myoma..
\end{abstract}

Method: This research is a descriptive research with cross-sectional design. Data collection is primary data in 2015.

Results: The study used 74 study subjects, 27 patients who were diagnosed with uterine myoma and 47 patients who were diagnosed with other obstetric diseases. Bivariate analysis showed that there was no relationship between age and parity of patients with the incidence of uterine myoma $p=0.840$ and 0.324 , there was a significant relationship between the age of menarch and the use of contraception to the incidence of uterine myoma $(p=0.002[(\mathrm{OR} 6.7) 95 \%$ Cl2.027-22.3] and $(p=0.003$ [(OR) 8.6 (CI) 95\% 2.1-35.2].

Conclusion: Women who suffer from uterine myoma are $>30$ years, with parity $>3$ and menarch age $<15$ years and using hormonal contraceptives associated with uterine myoma. Suggestion: For health workers can provide information and early screening / early detection on patients, especially on patients who have risk factors.

Keywords - myoma, menarch, hormonal control

\section{INTRODUCTION}

Reproductive health, especially in women has a major and important influence on the continuation of the next generation. It is said that reproductive health in woman is also a parameter in providing health services to the community. Although myomas rarely cause mortality, the resulting morbidity is quite high because uterine myomas are the most common cause of surgery and even hysterectomy.

The incidence of uterine myoma continues to increase in the United States this incidence is 2-12.8 people by 1000 women each year [1]. Research in Nigeria (Department of Gynecology, University of Nigeria) found that the prevalence of uterine myoma was $9.8 \%$, whereas research in Indonesia in 2008 found uterine myoma around 19.8\%, and in 2009 was $11.70 \%$ from other studies getting $2.39 \%-11.70 \%[2][3]$. According to research in the gynecology room Prof. Hospital Dr. Margono Soekardjo Purwokerto prevalence of uterine myoma reached 63.0\% [4] while according to in Zainoel Abidin Regional Hospital in Banda Aceh the incidence of uterine myoma ranked fifth out of ten gynecological diseases and was the most frequent case of $7.04 \%$.

Although several factors can encourage the formation of a myoma, but certainly cause are unknown, but there are some supporting unclear cause. Based on the results of the study all the results are still limited to estimates and uterine myoma is one of the many diseases that are frightening for women. Based on the results of the study the formation of myomas due to by family history with myoma, race, first menstruation before reaching the age of 10 years, alcohol consumption, uterine infections and hypertension, obesity and nullipara. The findings also found that pregnancy and birth control pills were thought to reduce the tendency to develop this myoma. In early pregnancy about $30 \%$ of myomas will enlarge and shrink back after giving birth. Although the hormone estrogen seems to be able to stimulate the growth of myomas, myomas will usually shrink after menopause.

Hormonal contraceptives consist of pills, injections and implants containing estrogen, in the form of a combination of progestin with estrogen or progestin. These contraceptives are considered the most effective and widely used by acceptors. According to the 2007 Indonesia Basic Health Survey (SDKI), the majority of women get married in Indonesia and they choose contraceptive and injectable devices according to the community this will be more practical, but the consequences that arise such as osteopenia, uterine myoma etc. are generally not considered. Based on these problems, the authors are interested in conducting research on 'Factors related to the occurrence of uterine myomas'. The purpose of this study is to obtain a description of the factors related to the occurrence of uterine myomas. 


\section{METHODS}

The study was conducted in the Midwifery Section of General Hospital in August to November 2015 with independent variables (age, education, occupation, parity, IMT menarch and family planning) while the dependent variable was myoma.

The design of this study was descriptive using a cross-sectional approach. The population in this study were all Obstetric and Gynecologic patients both in the clinic and in the ward and had undergone USG procedures with the inclusion criteria: not being pregnant and her uterine myoma could not be assessed. The minimum sample size is 74 people, the sampling technique is non-random. After getting the data, then processed and analyzed univariately to find out the frequency distribution of each variable and bivariate is done to see the relationship between the independent variable and the dependent variable. With the Chi Square test or Fishers Exact Test with the level of significance ( $\alpha$ 0.05) and CI $95 \%$.

\section{RESULTS AND DISCUSSION}

Table 1. Frequency distribution of uterine myoma patients in General Hospital

\begin{tabular}{lll}
\hline Occurrence of uterine myoma & Frequency & Percentage (\%) \\
\hline Not in myoma & 47 & 63.5 \\
\hline Myoma & 27 & 36.5 \\
\hline Total & 74 & 100.0 \\
\hline
\end{tabular}

Based on table 1 shows that the incidence of uterine myoma in patients was $27(36.5 \%)$ and those not in myoma were $47(63.5 \%)$.

Uterine myoma is a benign tumor of the uterine muscle. The number of sufferers of uterine myoma is difficult to know accurately because many do not cause complaints so that patients do not check themselves to the doctor. Until now, the exact cause of uterine myoma is unknown and is suspected to be a multifactorial disease. In General Hospital, the incidence of uterine myoma was $36.5 \%$, while in the researchers the prevalence of uterine myoma patients in the Obstetrics Section of Gynecology, Prof. Dr. Dr. RDandand Manado reached $108(30.6 \%)$ this figure is higher than the results of other studies such as getting a myoma case of 19.8\%, and from other studies getting 2.39\% -11.70\% [3].

Table 2. Distribution of age frequency, and parity of Midwifery patients in General Hospital

\begin{tabular}{lll}
\hline Age & Frequency & Percentage (\%) \\
\hline $20-30$ & 18 & 24.3 \\
\hline$>30$ & 56 & 75.7 \\
\hline Paritas & & \\
\hline $0-3$ & 23 & 31.1 \\
\hline$>3$ & 51 & 68.9 \\
\hline Total & 74 & 100.0 \\
\hline
\end{tabular}

Patients ranged in age from 22 to 57 years, with a mean value of 36.24 years with a standard deviation of 7.341 years. After categorizing, the results are $56(75.7 \%)$ over 30 years old. Based on parity ranging from 0 to 6 people with a mean value of 2 and SD 1. After categorizing the majority with parity> 3 a number of $51(68.9 \%)$.

Table 3. Frequency distribution of menarchic age, BMI and Contraception in Midwifery patients in General Hospital

\begin{tabular}{lll}
\hline Menarchic age & Frequency & Percentage $(\%)$ \\
\hline$<15$ years & 57 & 77.0 \\
\hline$\geq 15$ years & 17 & 23.0 \\
\hline BMI & & \\
\hline$<27$ percentil & 34 & 45.9 \\
\hline$\geq 27$ percentil & 40 & 54.1 \\
\hline Contraception & & \\
\hline Hormonal & 61 & 82.4 \\
\hline Non Hormonal & 13 & 17.6 \\
\hline Total & 74 & 100.0 \\
\hline
\end{tabular}


The age of menarche in obstetric patients at General Hospital is between 9 and 17 years, with a mean value of 14 years and SD of 1.16 years. After being categorized, the age of menarche $<15$ years is $57(77 \%)$. Furthermore, for the Body Mass Index (BMI) an average of 25.5 presentations and after being categorized then $\geq 27$ present 40 (54.1\%). While contraception which is widely used is injection $48(64 \%)$ but after being categorized then hormonal contraception users are $61(82.4 \%)$.

Table 4. Relationship characteristics with the occurrence of uterine myomas

\begin{tabular}{llllll}
\hline \multirow{2}{*}{ Age } & \multicolumn{2}{c}{ Myoma } & Total & p value & \multirow{2}{*}{ OR } \\
\cline { 2 - 4 } & Non Myoma & Myoma & & \\
\hline $20-30$ & $15(83.8 \%)$ & $3(16.7 \%)$ & $18(100 \%)$ & 3.75 \\
\hline$>30$ & $32(57.1 \%)$ & $24(42.9 \%)$ & $56(100 \%)$ & 0.84 & $(0.9-14.4)$ \\
\hline Paritas & & & & & 1.98 \\
\hline $0-3$ & $17(73.9 \%)$ & $6(26.1 \%)$ & $23(100 \%)$ & & $(0.6-5.8)$ \\
\hline$>3$ & $30(58.8 \%)$ & $21(41.2 \%)$ & $51(100 \%)$ & 0.324 & \\
\hline
\end{tabular}

From 18 people aged 20-30 there were $15(83.3 \%)$ people who did not have myoma and only $3(16.7 \%)$ people with myoma. From 23 people who have parity of 0 - 3 people who occur in uterine myoma as many as 6 people (26.1\%). Whereas those with high education were 12 people who experienced myoma as many as 7 people (58.3\%) and those who did not work and there were 11 myomas $(26.1 \%)$.

Statistical test results for the characteristics of the four variables have no relationship with the occurrence of uterine myomas.

By the age, most cases of myoma sufferers are > 30 years old (42\%) compared to those aged 20-30 years, and there is no relationship between age and uterine myoma. This is consistent with the theory that the risk of uterine myoma increases with age. The results of this study are not different from the findings of the research that the most age is 34-49 years $(93.5 \%)$ [5]

The results of research on 2014 found that the highest proportion of age in the group $>35$ years with a percentage of $77.8 \%$ [6]. While the results of the study Qonita Wachidah (2011) showed that $56.5 \%$ of patients with uterine myoma taste from the age group $>40$ years of uterine myoma results obtained in women aged $>35$ years $(73.8 \%)$ and rarely found in women aged 20 years [4]. In general, the incidence of uterine myoma is predicted to reach $20-30 \%$ occur in women aged over 35 years [7].

In this study also showed that cases of uterine myoma suffered more in women with parity of more than three or who had given birth. This is consistent with the study of Devi Isella Liliani et al on 2012 which states that uterine myomas often occur in women who have given birth with a percentage of $77.9 \%$ [3]. This result is also supported by research conducted by the research on 2012 which states that uterine myomas often occur in women with multiparous parity status [8]. Uterine myoma is more common in nulliparous or infertile women. Heredity also plays a role. The results of this study showed that there was no significant relationship between parity status and the incidence of uterine myoma. Although the results of the study showed that there was no significant relationship between parity status and the incidence of uterine myoma, it was probably caused by several factors, including nutritional intake consumed, contraception and people's lifestyle.

Table 5. Relationship between age of menarch, BMI and contraception with the occurrence of uterine myomas.

\begin{tabular}{|c|c|c|c|c|c|}
\hline & \multicolumn{2}{|c|}{ Myoma } & \multirow[t]{2}{*}{ Total } & \multirow[t]{2}{*}{ p value } & \multirow[t]{2}{*}{ OR } \\
\hline & Non Myoma & Myoma & & & \\
\hline \multicolumn{6}{|l|}{ Menarc } \\
\hline$<15$ years & $42(73.7 \%)$ & $15(26.3 \%)$ & $57(100 \%)$ & & 6.7 \\
\hline$\geq 15$ years & $5(29.4 \%)$ & $12(70.6 \%)$ & $17(100 \%)$ & 0.002 & $(2.03-22.3)$ \\
\hline \multicolumn{6}{|l|}{ BMI } \\
\hline$<27$ percentil & $20(42.6 \%)$ & $14(51.9 \%)$ & $34(100 \%)$ & & 68 \\
\hline$\geq 27$ percentil & $27(57.4 \%)$ & $13(48.1 \%)$ & $40(100 \%)$ & 0.59 & $(0.266-1.780)$ \\
\hline \multicolumn{6}{|l|}{ Contaception } \\
\hline Hormonal & $44(72.1 \%)$ & $17(27.9 \%)$ & $61(100 \%)$ & & 8.6 \\
\hline Non hormonal & $3(23.1 \%)$ & $10(76.9 \%)$ & $13(100 \%)$ & 0.003 & $(2.1-35.2)$ \\
\hline
\end{tabular}

First, pregnancy can facilitate the formation of adenomyotic foci into the myometrium due to the invasion of trophoblasts by invasive stretching of myometrial fibers. Second, the possibility of iatrogenic adenomyosis due to cesarean section during childbirth. Third, hormonal influences during pregnancy play an important role in the 
development of ectopic endometteria.

From 12 patients who had menarche age $<15$ years there were 57 people and those suffering from myomas 15 people (26.3\%) test results with $\mathrm{P}$ values 0.002 and OR 6.7. For BMI <27 present, there were 34 people, suffering from myoma14 (41.2\%), with a p-value of 0.596 . Furthermore, the majority of contraceptives used were hormonal with 61 people, while those suffering from myomas totaled 17 (27.9\%) with p values of 0.003 and OR 8.6 meaning that there was a significant relationship between hormonal contraception and the incidence of uterine myoma.

The results of the study at the age of menarche, of 74 people aged menarche less than 15 years, amounted to 57 people and those suffering from myoma 15 people, while those aged menarche more than 15 years, amounted to 17 people who suffered from myoma. 12 people test results known $\mathrm{p}$ value $=0.002$ a significant relationship between the age of menarche and the incidence of uterine myoma, while OR 6.7 means that the age of menarche $<15$ years increases the risk of uterine myoma (6.7 times) and age of menarche $\geq 15$ years can reduce the risk of uterine myoma. Devy et al at the Tugurejo District Public Hospital Semarang stating that menarche $>10$ years can reduce the risk of uterine myoma $1.24(\mathrm{OR})$.

F61 people who use hormonal contraception 17 people $(27.9 \%)$ suffer from uterine myoma with a p value. 0.003 and OR 8.6 means that those who use hormonal contraception (pills, injections, inplants) have 8.6 times the risk of uterine myoma compared to those using non hormonal contraception (iud, etc.).

This condition is the same as the results of Pojianto's study which found that the incidence of uterine myoma will increase at the age of 35-50 years. This shows that there is a relationship between the occurrence of uterine myoma with the hormone estrogen. Different from the results of research by Lilyani DI which states: hormonal with the incidence of uterine myoma $(\mathrm{p}=0.859)$.

In the hormonal contraceptive method associated with an unbalanced lifestyle, this will cause disruption of the hormone and the possibility of uterine myoma. The size of the uterine myoma is also influenced by hormonal factors, the number of calories and genetic factors.

\section{CONCLUSIONS}

Uterine myomas are more common in women > 30 years old. Patients with uterine myomas occur more in the parity of $>3$ children and myoma sufferers are more common in women with menarche $<15$ years of age and in users of hormonal contraception.

\section{SUGGESTION}

For health workers can provide information and initial screening / early detection in patients, especially in patients who have risk factors.

\section{ACKNOWLEDGEMENT}

Ethical clearance for this study was granted by Health Polytechnic Ministry of Health Jakarta III.

\section{REFERENCES}

[1] Kang dkk, 'Up-regulation of Apoptosis by Gonadotrophin-releasing Hormone Agonist in Cultures of Endometrial Cells from Women with Symptomatic Myomas', Human Reproduction, 2010.

[2] Okezie; Ezegwui, H.U, 'Management of Uterine Fibroids in Enugu, Nigeria', Journal Obsteteric Gynaecology 26 (4), 2006.

[3] Devy, IL; Sudiat, Muhammad; Basuki, Rochman, 'Hubungan Faktor Risiko dan Kejadian Mioma Uteri di RSUD Tugurejo', Jurnal Kedokteran Muhammadiyah, Vol 1, No1, Semarang, 2012.

[4] W, Qonita; AS, Islimsjaf; Aditiyono, 'Hubungan Hiperplasia Endometrium Dengan Mioma Uteri: Studi Kasus Pada Pasien Ginekologi RSUD Prof. Dr. Margono Soekardjo Purwokerto’. Mandala of Health, Volume 5, Nomor 3, Jawa Tengah, 2011.

[5] Pratiwi, Lilis; E , Suparman; F , Wagey, 'Hubungan Hiperplasia Endometrium Dengan Mioma Uteri', Jurnal eCliniC (eCl), Volume 1, Nomor 1, 2013.

[6] Wati , Evita, 'Hubungan Karakteristik Pasien Terhadap Kejadian Mioma Uteri-Adenomyosis Di RS UD Dr Sudarso Kalimantan Barat', Skripsi Fakultas Kedokteran Universitas Tanjungpura, Pontianak, 2014.

[7] P, Wiknjosastro; H. Sumapraja, 'Ilmu Kandungan (Edisi Ketiga)' Yayasan Bina Pustaka Sarwono, Jakarta, 2011.

[8] Pertiwi, Dewi Kirana dkk, Hubungan Usia Menarche dan Paritas dengan Kejadian Mioma Uteri di RSUD Wates Kulonprogo Tahun 2007-2010', Jurnal Penelitian Kesehatan Suara Forikes, vol III, no. 3, 2012. 